\title{
Sight Beyond Sight: Foreseeing Fraudulent Financial Reporting through the Perspective of Islamic Legal Ethics
}

\author{
Dien Noviany Rahmatika ${ }^{1}$, Achmad Irwan Hamzani², Havis Aravik ${ }^{3}$, \\ and Nur Rohim Yunus ${ }^{4}$
}

\begin{abstract}
In the financial sectors, fraud has become a world phenomenon, ranging from fraudulent financial reports, assets misappropriation and corruption. These three types of fraud are practices carried out deliberately against the law which harm many parties. This study aims to analyze fraudulent financial reporting, where the presentation of misstatements is presented to mislead financial reports. These are against the ethical perspective of Islamic law as stated in the Quran and Hadith. This research uses secondary data based on the principles of sharia accounting concepts and Islamic ethics. The analytical method used is a qualitative description method with literary and normative approaches by examining fraudulent financial reporting from the perspective of Islamic law. The results of this study strengthen the theory of fraud pentagon with the symptoms and red flags of fraud, namely pressure, opportunity, rationalization, competence, and arrogance of the perpetrators of fraud. The Quran as well as the hadith emphasize the values of honesty, justice, truth, responsibility, and belief in reporting. This research also overlooks the weak ethics of the accounting profession and also the value of religiosity held by weak accountants from the perspectives of Islam.
\end{abstract}

Keywords: Accounting Fraud, Fraudulent Financial Reporting, Fraud Pentagon Theory, Islamic Legal Ethics

Abstrak. Pada sektor keuangan, fraud (kecurangan) menjadi salah satu fenomena global, dengan kasus kecurangan laporan keuangan, penyelewengan aset dan korupsi. Ketiga bentuk kecurangan tersebut merupakan praktek yang dilakukan secara sengaja melawan hukum dan merugikan banyak pihak. Penelitian ini bertujuan untuk menganalisis kecurangan pelaporan keuangan, dimana informasi yang disajikan dalam laporan adalah hal yang tidak sesuai dengan kenyataan. Hal ini bertentangan dengan etika bukum Islam dalam Al-Qur'an dan Hadits. Penelitian ini adalah menggunakan data sekunder dengan mendasarkan pada prinsip-prinsip akuntansi syariah dan etika Islam. Metode analisis yang digunakan adalah metode deskripsi

1, 2Universitas Pancasakti Tegal 
kualitatif dengan pendekatan literatur dan kajian normatif. Hal ini dilakukan dengan memeriksa kecurangan pelaporan keuangan dari perspektif hukum Islam. Hasil dari penelitian ini memperkuat teori Fraud Pentagon tentang gejala dan Red Flag Fraud, yang terdiri dari tekanan, peluang, rasionalisasi, kompetensi, dan arogansi para pelaku penipuan. Hal ini bertentangan dengan prinsip hukum Islam yang menekankan pada nilai-nilai kejujuran, keadilan, kebenaran, tanggung jawab, dan kepercayaan dalam pelaporan. Penelitian ini juga menunjukkan lemahnya prinsip etis dalam profesi akuntansi dan jugai religiusitas yang dimiliki oleh akuntan.

Kata kunci: Kecurangan akuntansi, Kecurangan Pelaporan Keuangan, Teori Fraud Pentagon, Etika Hukum Islam

\section{Introduction}

Accounting has undergone many developments and advancements along with current technological and information developments. The need for financial information continues to progress to meet the demands and needs of the economy in society, especially in the business world. This is to continuously improve the implementation of comprehensive economic development (Yurmaini, 2017). The development of accounting concepts must also be followed by good morals to maintain transparency over financial information presented in financial reports that can be accounted for by management.

A financial report is the information used by the users of the financial statement to make economic decisions (Astuti, \& Zuhrohtun, 2015; Akbar, 2017). In addition, the financial report is an important communication tool between the manager and stakeholders, so the provided information must be reliable or the presented information is having zero mistakes (Ulfah, et al., 2017). In accounting, there are two terms of mistakes, namely unintentional mistakes (errors) and intentional mistakes (fraud). Both of these terms are very difficult to distinguish, so it is necessary to have a special inspection to determine misstatements in the financial reports. If the mistake is intentional then it can be regarded as an act of fraud (Karyono, 2015: 13).

Some of the phenomena that cause fraud are the lack of supervision carried out by internal auditors, the code of conduct of company leaders, weak governance, and an unfavorable ethical work climate in the company (Albrecht and Albercht, 2011). This phenomenon has resulted in several studies that focus on professional ethics possessed by auditors and leaders. Because the mayority 
of Indonesians are Muslims, the research will also be based on the primary sources of Islam, which are the Qur'an and Hadith. These guidelines are often violated by auditors and companies as proven by the many cases of fraud that have occurred in Indonesia

Fraud in Islam is strictly prohibited and is included in a despicable act because it contains "mudharat" which can harm many parties. Within the framework of Islamic teachings, all economic activities developed by humans must be guided by ethics and morality in Islamic law (Yurmaini, 2017). The principle of Islamic economic lies in the context of "muamala" with a sense of mutual needs and helps in achieving success. Therefore, the guideline is to make humans have good morals in doing business and obtaining good fortune given by God in a halal and clean way without containing any prohibited acts (Sari, et al., 2017).

Qur'an Surah al-Zariat: 56 mentions the aims of the creation of Allah's creatures. The verse says: "I did not create jinn and humans except to worship Me" (Q.S al-Zariat: 56). This verse confirms that Allah created jinn and humans solely to worship Him. The implication is that as a Muslim, every action carried out must truly be guided by the provisions of God that are based on the Quran and Hadith so it is clear for what is halal (allowed) and what is haram (forbidden) (Siregar, 2015).

The objective of the paper is to analyse the phenomena that often occur in the business world, in which one of them is about accounting fraud (fraudulent financial reporting). This analysis is expected to show the factors that can influence accounting fraud and provide solutions to existing problems and explain how the phenomenon is viewed from the ethical perspective of Islamic law. This paper is expected to explain how to prevent and detect fraudulent financial statements, especially from the perspective of accountant professionalism.

\section{Theoritical Framework}

\section{Accounting theory}

Accounting theory studies the recording or measurement of a value. Accounting is an art of recording, journalizing and classifying an economic transaction that is then posted to each account/post to produce financial information. In practice, accounting is better known for recording activities in the business to produce financial information.

Financial statements must contain information that can be used for 
decision making in the future. Therefore, the quality of financial statements must be reliable so that they can be used as the basis for good decision making (Kusumaningtyas, 2016). The existence of accounting in society is influenced by many factors that result in variety of accounting forms and applications. Factors that influence accounting are the economic system, laws, and regulations, social and political as well as culture and values that develop in the community (Harkaneri, 2013). The financial statement must present complete information from the name of the entity, report name, reporting date, reporting period, and types of transactions to supporting information to make it easier for others to read and understand the contents of the financial statements (Syaiful, 2017).

\section{Fraud Theory}

Fraud is generally defined as an intentional act of deception or lying, a deception or a dishonest way to make or lose money, property, legitimate rights of others either because of an action or the fatal impact of the action itself (Arens, 2014). In another opinion, fraud is an action that is carried out by using the level of intelligence of an individual to gain an advantage or benefit from other people in a wrong or misleading way. Fraud will not occur without the right person with the right abilities. The ability element in fraud detection is considered because fraud will involve people who have the ability to commit (Albercht and Albercht, 2011).

Rezaee and Riley (2010) stated that fraud is an intentional mistake or makes wrong information with the aim of committing fraud or forgery. Fraud in its development is classified into three major typologies based on the type of action (ACFE, 2014; Priantara, 2013: 68; Rahmatika, 2016), namely:

a. Misappropriation asset

Misappropriation asset is an act of misuse, embezzlement and/or theft of company wealth or assets carried out by internal or external parties of the company. This fraud is tangible or can be assessed and calculated. Misappropriation asset is usually identical to employee fraud because most of the perpetrators are in the level of company employees.

b. Fraudulent Statement

Fraudulent statements or in-purpose incorrect statements can be interpreted as a type of fraud that is categorized in the act of which most of the perpetrators are in the management, executive officers or officials / senior 
management. This type of fraud is usually committed by manipulating a piece of information in the company to cover up or manipulate the company's finances for personal or group interests. Fraudulent Statement can be termed as accounting gimmicks, window dressing, illegal earnings management, income smoothing, fraudulent in financial reporting and so on.

c. Corruption

Corruption is a type of fraud that is difficult to be detected. This type of fraud usually involves parties who have the authority and interests and are carried out systematically and structured. To uncover cases of corruption, it is necessary to have superior and competent human resources who have investigative skills and experience. The example of corruption acts that often occur is by handing gifts illegally (gratuities) and extortion.

The factors that led to fraud had developed since 1953 it is known as the fraud triangle. Then more and more cases of fraud occurred, the theory of fraud was further developed by Wolfe and Hermanson (2004) into diamond fraud. And the most recent theory is the pentagon fraud developed by Crowe (2011) which said that the factors that encourage fraud are divided into 5 (five) factors, are

a. pressure, a motivation that comes from inside of a person or pressure from others that encourages someone to commit fraud;

b. opportunity, a condition where someone has an opportunity or chance to commit fraud;

c. rationalization, an attitude of justification from fraud perpetrators who assume that the taken actions are not wrong but the actions taken for the benefit of the company;

d. competence, a skill possessed by individuals to commit fraud, so with their skills it is easy to get benefits personally; and

e. arrogance, an attitude of being imperious and haughty possessed by someone by believing that all the rules that have been made will not ensnare him or others will not know the acts of fraud committed. 


\section{Figure 1. Fraud Pentagon}

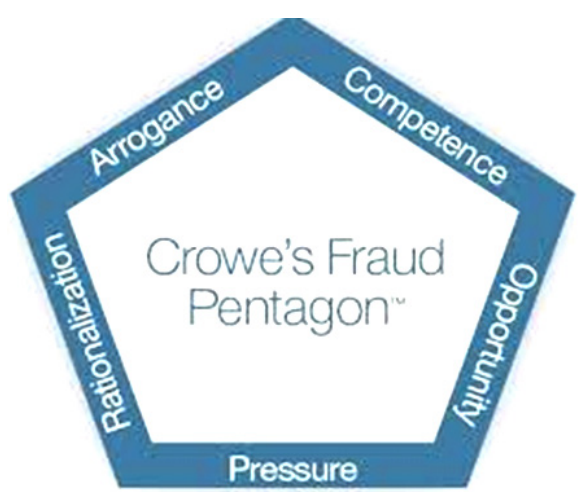

Source: Crowe (2011)

\section{Fraudulent Financial Reporting}

Fraudulent financial reporting can be interpreted as an act of falsifying and deceiving the financial report user by providing the information contained in the financial reports which are not in accordance with the real conditions and eliminating some numbers or nominal (ACFE, 2016). This intentional error is caused by a company's financial condition made by making a false presentation report or other errors of the figures or disclosure of financial statements to get the financial report user (Yulianti, Pratami, \& Prapti, 2019; Rahmatika et al., 2019). The company manager usually does fraudulent financial reporting to deceive investors by increasing the amount of assets and income or reducing the amount of debt (liabilities) and the costs charged to the company.

\section{Accounting in the perspective of Islamic law}

Economic transactions have experienced many developments ranging from simple transactions to transactions that use sophisticated technology or online (Alma, 2016). To support economic activities, an accounting system is needed. In Islamic law, the way to mention accounting which based on the teachings of Islam is sharia accounting. The sharia accounting is made and developed based on the rules of the Islamic law that have been ruled by Allah SWT through the Qur'an and Hadith that should be obeyed by Muslim (Fauzan and Sulistyo, 2016).

According to Harkaneri (2013), accounting in Arabic is called muhasabah. Muhasabah in the Quran is mentioned 48 times. There are eight definitions of 
mushasabah, and they are: accountable; expecting the reward of the afterlife; being neutral; trying to achieve. Yahsaba means counting or measuring or judging; it also means continuous recording and calculation. Hasaba means completing responsibilities; and tahasab means guarding

In addition, some verses in the Quran explain the problem of muamalah or what is often referred to as trading activities, debts, and leases. One of the verses describing the problem is in Q.S Al-Baqarah verse 282. It says:

"O You who have believed, when you contract a debt for a specified term, write it down. And let a scribe write [it] between you in justice. Let no scribe refuse to write as Allah has taught him. So let him write and let the one who has the obligation dictate. And let him fear Allah, his Lord, and not leave anything out of it. But if the one who has the obligation is of limited understanding or weak or unable to dictate Himself, then let his guardian dictate in justice. And bring to witness two witnesses from among your men. And if there are not two men [available], then a man and two women from those whom you accept as witnesses - so that if one of the women errs, then the other can remind her. And let not the witnesses refuse when they are called upon. And do not be [too] weary writing it, whether it is small or large, for its [specified] term. That is more just in the sight of Allah and stronger as evidence and more likely to prevent doubt between you, except when it is an immediate transaction which you conduct among yourselves. For [then] there is no blame upon you if you do not write it. And take witnesses when you conclude a contract. Let no scribe be harmed or any witness. For if you do so, indeed, it is [grave] disobedience in you. And fear Allah. And Allah teaches you. And Allah knows of all things." (Q.S Al-Baqarah: 282).

The above verse explains that Allah SWT has given instructions to humans regarding the rules of a transaction that must be carried out, namely recording (khitabah), the appointment of a witness and note-taker. There is also the principle that need to be considered to achieve justice, transparency, truth, and certainty by both parties, which in the nature of accounting is called accountability (Suryanto \& Dwisaputro, 2016). Sharia accounting rules are a standardized and permanent collection of Islamic laws, sourced from Islamic law and are used by an accountant in carrying out his work, such as accounting, recording, exposure, and measurement of an event or transaction (Ibrahim, 2010). 
The diversity of economic transactions makes it difficult for humans to remember all the cases or incidents. Therefore, reasonably good accounting system based on the needs and circumstances is needed. The system designers work hard to be able to find an effective and efficient system that can be controlled and accounted for (Hadibroto, 1984: 8). Allah gives guidance to humankind by sending down the Quran to be used as a guide in life. It is explained in Q.S. Al-Ma'idah verse 16:

"By which Allah guides those who pursue His pleasure to the ways of peace and brings them out from darknesses into the light, by His permission, and guides them to a straight path." (Q.S. Al-Ma'idah; 16).

In Islamic teachings, there are principles of aqidah, ethics, muamalah, and worship in which the three of them are a related entity. If humans implement muamalah, which is the basic values in sharia, then they are practicing aqidah or monotheism. If the values contained in sharia are appropriately implemented, it will form a person with the morality of mercy. This will benefit many people (Kusumaningtyas, 2016).

Accounting in Muslim societies should be arranged based on Islamic teachings. Islam regulates all aspects of the accountant profession which is not only about worldly matters but also to offer all parties, management and investors, to achieve the benefit of the world and the hereafter (Harahap, 2008). This is of course in line with the purpose of financial statements in accounting where most of their users are related parties such as investors, creditors, suppliers, employees, consumers, government, and companies to make decisions based on the available information (Yulianti et al., 2019).

\section{Research Method}

This research is a qualitative descriptive study that used a normative approach and library research. The data analysis method used is qualitative by organizing and sorting data into basic patterns, categories and description units so that themes can be presented in narrative form. The data will be presented in a narrative-descriptive manner, not in a numerical form. A normative approach is used as a source of guiding rules derived from the holy book of the Quran, which will later be associated with phenomena that occur in this study. Besides, research with the literature approach method is an activity by collecting several types of relevant reading sources to support the quality of the object of research through the deepening of the literature. 
Data used in this study is secondary data in the form of literature under the research topic, namely from scientific journals, reference books, papers and articles that discuss accounting fraud and the ethical perspective of Islamic law. Data collection techniques are done through a conventional and online search. The conventional library search is the activity of looking for sources of libraries to the data storage. Whereas, the online study is an activity to find library resources in cyberspace through the internet network. Besides, there are two stages carried out in the study, namely the description stage and the analysis phase. The description phase is the stage to explore the factors that can encourage fraudulent in financial reporting viewed from Islamic legal ethics and theories. The analysis stage is the stage of analyzing the concept used as a reference for assessing accounting fraud in the perspective of Islamic legal ethics. This paper also explains how to prevent and detect fraudulent financial statements, from the perspective of accountant professionalism.

\section{Discussion}

\section{Fraud in Islamic View}

In Islamic teachings, ethics is the primary basis for guiding people in all aspects of life to achieve the highest success. Rules, recommendations, and prohibitions are all contained in the Qur'an. Allah describes the people who achieve success are those who are able to direct their actions in goodness, encourage people to do right (máruf) and forbid people to do wrong (munkar) (Harkaneri, 2012).

Fraud is very contrary to the view of Islamic law. Fraud is an act that can harm many people, while Islam teaches its adherents always to take actions that can benefit people (Yurmaini, 2017). Islam strongly rejects all forms of fraud because cheating fundamentally contains harmful / "mudharat" for many parties and violates the moral values that contained in the teachings of Islam. This is because the purpose of Islamic law is to preserve religion, life, intellectual or mind, descent and wealth. Humans only serve as caliphs, to maintain and develop all the material owned by Allah in a halal way (Suryanto \& Dwisaputro, 2016).

The prohibition of fraud is explained the Qurab, Surah Al-Mutaffifin verses 1-6, stating;

"Wo to those who deal in fraud, those who, when they have to receive by measure from men, exact full measure, but when they have to give by measure or weight to men give less than due. Do they not think that they will be 
called to account on a Mighty Day, a Day when (all) humankind will stand before the Lord of the Worlds? (Al-Mutaffifin 83: 1-6).

Based on the above verse, Islam condemns those who are fraudulent with great punishment. Among them are the people who are insincere when give measurement. The act of reducing weight than due or giving a less than one should receive is considered fraud and those who engage in such actions will face severe punishment (Ibrahim, et al., 2013). Islamic business ethics is relevant to be developed continuously as the solution to the problems faced in the recent era with the hope of creating a clean and healthy business that can provide benefits to many parties (Ibrahim, 2010).

\section{Islamic Ethical Perspective on Fraudulent Financial Reporting}

Fraudulent financial reporting is an act that deceives or falsifies the information contained in financial reports for personal gain. In the Islamic view, fraudulent financial reporting is identical to deceptive acts or fraudulent. An explanation of the prohibition on fraud is explained in the Quran as follows:

a. Q.S. Ali-Imran verse 161: "It is not [attributable] to any prophet that he would act unfaithfully [reagrding war booty]. And whoever betrays, [taking unlawfully], will come with what he took on the Day of Resurrection. Then will every soul be [fully] compensated for what it earned, and they will not be wronged.

b. Q.S. al-Nisaa verse 29: "O you who have believed, do not consume one another's wealth unjustly but only [in lawful] business by mutual consent. And do not kill yourselves [or one another]. Indeed, Allah is to you ever, Merciful."

c. Q.S. Al-Ma'idah verse 38: "[As for] the thief, the male and the fermale, amputate their hands in recompense for what they committed as a deterrent [punishment] from Allah. And Allah is exalted in Might and Wise."

d. Q.S. al-Syura verse 42: "The cause is only against the ones who wrong the people and tyrannize upon the earth without right. Those will have a painful punishment."

\section{Prevention and Detection Fraud}

A strategy to minimize fraud is carried out using a fraud prevention model (Rezaee and Riley, 2010; Singleton, and Singleton, 2010; Arens and Beasley, 2014). Several studies have considered the prevention model and it has undergone many developments. The authors combine two factors in this 
development model, specifically looking at the Islamic side of professional ethics accounting and in terms of religious values

Fraud prevention concept is the selection of policy, systems, and procedures by the management to assist supervision and control in a company to minimize fraud. The aim is to produce reliable, efficient and effective, and law-based financial reporting. The following are some solutions to fraud prevention.

Table 1. Fraud Prevention Concept

\begin{tabular}{|c|c|c|c|}
\hline No & Fraud Prevention & Concept & Source \\
\hline 1 & $\begin{array}{l}\text { Create a culture that } \\
\text { values honesty }\end{array}$ & $\begin{array}{l}\text { - Responsibility to grow and appreciate the values } \\
\text { of honesty to each of its members } \\
\text { - Honesty values by top management to } \\
\text { employees through their words and moral } \\
\text { hazard that cannot be tolerated even if it } \\
\text { benefits the company }\end{array}$ & $\begin{array}{l}\text { Rezaee and Riley } \\
(2010) ; \\
\text { Singleton, and } \\
\text { Singleton, (2010); Arens } \\
\text { and Beasley, (2014) }\end{array}$ \\
\hline 2 & $\begin{array}{l}\text { Build a good internal } \\
\text { control structure }\end{array}$ & $\begin{array}{l}\text { - Creating an internal control structure to avoid } \\
\text { the loss of assets } \\
\text { - Control system includes integrity and ethical } \\
\text { values, carry out risk assessments, control } \\
\text { procedures, carry out monitoring to assess the } \\
\text { quality of work of the controls. }\end{array}$ & $\begin{array}{l}\text { Rezaee and Riley } \\
(2010) ; \\
\text { Arens and Beasley } \\
(2014)\end{array}$ \\
\hline 3 & $\begin{array}{l}\text { Develop supervision } \\
\text { processes }\end{array}$ & $\begin{array}{l}\text { - Good and appropriate supervisory function } \\
\text { - The development of the oversight process }\end{array}$ & $\begin{array}{l}\text { Arens and Beasley } \\
(2014)\end{array}$ \\
\hline 4 & $\begin{array}{l}\text { Improve the culture } \\
\text { of the organization }\end{array}$ & $\begin{array}{l}\text { - Good Corporate Governance } \\
\text { (Transparency, Justice, Accountability, } \\
\text { Responsibility, Morality, Reliability and } \\
\text { Commitment) }\end{array}$ & $\begin{array}{l}\text { Arens and Beasley } \\
(2014)\end{array}$ \\
\hline
\end{tabular}

The above fraud prevention concepts strengthen theories about overcoming symptoms and red flag fraudulent financial reporting (pressure, opportunity, rationalization competence, and arrogance). The addition of this research is to see from the other perspective of the weak ethics of the accounting profession and also the weakness of the value of religiosity held by accountants.

\section{a. Accountant professional ethics}

Ethics is a science that studies the good or bad in actions. Ethics can be called as akblaq. In Islamic teachings, akblaq becomes the most essential component in daily life and becomes a guide in carrying out a profession. An accountant's profession can be regarded as a fardu kifayah professional. This 
means that a Muslim must have good professional ethics in order to achieve the goal of ensuring the level of reliability of financial reports and increasing trust in the services provided by an accountant, in line with PSAK Standards

The basic principles that must be possessed by an accountant are as follows:(1) Integrity, (2) Accuracy, (3) Objectivity, (4) Confidentiality, and (5) Professionalism. These five principles must be applied in the process of preparing financial reports. In Islamic law, a person who is carrying out his or her profession must always pay attention to ethics and rules that have been made so that the results of the work done can provide benefits for many people.

The weak professional ethics of an accountant can produce irrelevant and misleading financial reports. This is what can encourage an accountant to commit acts of deviation to seek personal profits because they are unable to maintain the ethical commitments of the existing profession. Islam strictly forbids all actions carried out in a way that is unlawful because Islam teaches the value of honesty and responsibility, as someone faces consequences of his or her actions.

\section{b. Religiosity value}

Religiosity is a view owned by humans to choose a good thing based on the teachings of the religion they profess. Religiosity will bring human life to happiness because they know where their lives will be taken, and they know the purpose of their creation. This proves that religiosity is a process of forming behavior that is based on religious values with the aim of improving self-quality for each individual.

Religiosity must be able to be a work motivation for an accountant. A high religious value can motivate accountants to always be responsible for their work, so they are able to provide good quality financial reports. A trait possessed by humans who feel insatiable can threaten the state of the company. Therefore, the value of religiosity possessed by an accountant can prevent an accountant from committing an act of deviation.

The weak value of the religiosity of an accountant can have a significant impact on a company. It should be bearing in mind that the accounting profession is a job that must be carried out with great care and caution to produce reliable financial reports. People who have a low religious value tend to always think about themselves and do unethical actions for their own satisfaction. Besides, they are not eager to learn new things because of worldly considerations. Thus, the knowledge possessed by an accountant will not develop or in other 
words; the possessed competencies are insufficient. This is not in line with the ethical principles of the accounting profession, namely competent or careful, in preparing financial reports. Religious values will help accountants to remain in the prevailing professional ethics and naturally will feel afraid if they violate the commands of Allah SWT.

From some of the verses above, it is obvious that God, through the Quran, forbids all actions relating to fraud and will give punishment to those who commit fraud. For a Muslim, it has become an absolute thing that everything must be based on the Quran and Hadith to achieve success in this world and the hereafter. Therefore, the introduction of Islamic law into financial institutions is critical and will produce significant changes, especially in the way institutions run the business. This will undoubtedly affect their financial management (Kasim et al., 2013). In addition, studying issues related to securities law enforcement is very important, so that investors are guaranteed for the high-quality earnings in public companies, bearing in mind the increasing number of fraudulent financial reporting every year in various countries.

Fraud detection is carried out by identifying the symptoms that often indicate fraud. There are several pro-active fraud detection methods, including by looking at the symptoms and red flag of fraud. Another method is using the Inductive Detection Method and the Deductive Detection Method. Meanwhile, fraud in the presentation of financial statements is generally detected through financial statement analysis using vertical analysis, horizontal analysis and ratio analysis. (Albercht and Albercht, 2011 and ACFE, 2011)

All steps taken by auditors to prevent and detect are steps to reduce the existence of increasingly widespread fraud. However, the primary step is strengthening in terms of professional ethics, both auditors and company employees. This is because weak ethics is the beginning of the intention of fraud to occur.

\section{Conclusion}

Fraudulent financial reporting is one type of accounting fraud that is widely committed by management to commit fraud against shareholders. Factors that can lead to fraud include pressure, opportunity, rationalization, competence, and arrogance. This research sees the problem from 1) the weakness in the accounting professional ethics, or akblaqi; 2) the weakness of the value of religiosity held by accountants; 3) accountants' perspectives in fraud prevention and detection. It 
becomes fardhu kifayah (communally obligatory) for an accountant to have high professional, ethical values based on PSAK Standards. A high religious value can motivate accountants to be responsible in their work so they can provide good quality financial reports. Those who commit fraud or mismanagement must be punished. This is because the act is against the law as well as the Qur'an and the Hadith. Some of the violated values are honesty, justice, truth, responsibility, and trustworthiness. Islamic business ethics is relevant to be developed continuously as a solution to the contemporary problems. It is expected that such ethics will be able to create a clean and healthy business that can provide benefits to many parties. The principle of aqidah, ethics, muamalah, and worship are related entities. Islam regulates all aspects of the accountant profession, which is not only for the sake of the worldly matters, but also to create benefits for both management and investors in the world and hereafter.

\section{References}

Association of Certified Fraud Examiners (ACFE). 2011. Fraud Examination Manual, Third Edition.

Akbar, Taufiq. 2017. "The Determination of Fraudulent Financial Reporting Causes by Using Pentagon Theory On Manufacturing Companies In Indonesia”. International Journal of Business, Economics and Law, Vol. 14, (5).

Albrecht, W.S. and Albercht, C.O. 2011. Fraud Examination. Thomson SouthWestern.

Alma, Buchari. 2016. Manajemen Bisnis Syariah: Menanamkan Nilai Dan Praktik Syariah Dalam Bisnis Kontemporer. Jakarta: Avabeta.

Aprilia. 2017. "Analisa Pengaruh Fraud Pentagon terhadap Kecurangan Laporan Keuangan Menggunakan Beneish Model pada Perusahaan yang Menerapkan Asean Corporate Governance Scorecard.. Jurnal Akuntansi Riset, Vol. 6 (1).

Arens, A.A., R.J. Elder, M.S. Beasley. 2014. Auditing and Assurance Services: An Integrated Approach, $14^{\text {th }}$ Edition, Pearson, Prentice Hall Inc.

Association of Certified Fraud Examiners (ACFE). 2014. "Report to the Nations on Occupational Fraud and Abuse".

Astuti, Siti, Zuhrohtun, Kusharyanti. 2015. "Fraudulent Financial Reporting in Public Companies in Indonesia: An Analysis of Fraud Triangle and Responsibilities of Auditors". Journal of Economics, Business, and Accountancy Ventura, Vol. 18 (1). DOI: 10.14414/jebav.v18i2.821. 
Crowe, H. 2011. Why the fraud triangle is no longer enough. Horwath, Crowe LLP. Fauzan dan Sulistyo. 2016. "Etika dan Akuntansi Islam: Telaah atas Q.S. alBaqarah ayat 282". Prosiding Seminar Nasional dan Call for Papers Ekonomi Syariab"Indonesia Sebagai Kiblat Ekonomi Syariah.

Harahap, Sofyan Syafri. 2008. Analisis Kritis atas Laporan Keuangan. Jakarta: PT. Raja Grafindo Persada

Harkaneri, H. 2013. Urgensi Etika dalam Akuntansi Dilihat dari Sudut Pandang Islam. Jurnal El-Riyasah, 4(1), 48-58.

Ibrahim, Azharsyah. 2010. "Income smoothing dan Implikasinya terhadap Laporan Keuangan Perusahaan dalam Etika Ekonomi Islam”. Jurnal Media Syariah, Vol. XII (24).

Ibrahim, S. S., Man, N. C., \& Noor, A. H. M. (2013). Fraud: An Islamic Perspective. In The 5th International Conference on Financial Criminology (ICFC).

Karyono, 2015. Forensic Fraud. Jakarta: Andi Offset.

Kasim, Nawal, et. al. 2013. "Assessing the current practice of Auditing in Islamic Financial Institutions in Malaysia and Indonesia". International Journal of Trade, Economics and Finance, Vol. 4 (6).

Kusumaningtyas, Dian. 2016. "Religiusitas pada Motivasi dan Etika Profesi Akuntan Dalam Perspektif Islam”. Cendikia Akuntansi. Vol. 4, (1).

Pratiya, M. A. M. and Susetyo, B. 2018. "Pengaruh Stabilitas Keuangan, Target Keuangan Tingkat Kinerja, Rasio Perputaran Aset, Keahlian Keuangan Komite Audit, dan Profitabilitas Terhadap Fraudulent Financial Statement". Permana: Jurnal Perpajakan, Manajemen, dan Akuntansi. doi: 10.24905/ permana.v10i2.86.

Priantara, Diaz, 2013. Frand Auditing \& Investigation. Jakarta: Mitra Wacana Media Rahmatika, D. N. 2016. Determinant Factor Influencing the Level of Fraud and Implication to Quality of Financial Reporting (Research at Local Governments Indonesia). International Journal of Applied Business and Economic Research vol. 14, No. 14 (2016): 10187-10205

Rahmatika, D. N., Kartikasari, M. D., Indriasih, D., Sari, I. A., \& Mulia, A. 2019. Detection of Fraudulent Financial Statement; Can Perspective of Fraud Diamond Theory be applied to Property, Real Estate, and Building Construction Companies in Indonesia?. European Journal of Business and Management Research, 4(6). 
Rezaee, Z. and Riley, R. 2010. Financial Statement Fraud: Prevention and Detection. John Wiley and Sons. New Jersey - Canada.

Sari, Amik Nurlita., et. al. 2017. Analisis Praktek Kecurangan Timbangan Pada Pedagang Kebutuhan Pokok Ditinjau dari Etika Bisnis Islam.( Studi Kasus di Pasar Bandar Kecamatan Mojoroto Kota Kediri). Laporan Penelitian. Sekolah Tinggi Agama Islam Negeri (STAIN) Kediri.

Singleton, T.W. and Singleton, A.J. 2010. Fraud auditing and forensic accounting (Vol. 11). John Wiley \& Sons.

Siregar, Budi Gautama. 2015. Implemantasi Akuntansi Dalam Kehidupan Menurut Perspektif Islam. Implemantasi Akuntansi, Vol. 3, (1)

Suryanto, Tulus dan Anip DwiSaputro. 2016. Konsep Pencegahan Kecurangan (Fraud) Akuntansi dalam Perspektif Islam. Yogyakarta: CV Arti Bumi Intaran.

Syaiful, Moh. 2017. Management Laba (Earnings Management) dalam Tinjauan Etika Islam. Ekomadania. Vol. 1, (1).

Tunggal, Amin Widjaja. 2014. Mendeteksi Kecurangan Dalam Akuntansi. Jakarta: Harvarindo.

Ulfah, Maria. Elva Nuraina, Anggita Langgeng Wijaya. 2017. "Pengaruh Fraud Pentagon dalam Mendeteksi Fraudulent Financial Reporting (Studi Empiris pada Perbankan di Indonesia yang Terdaftar di BEI)". FIPA. Vol. 5 (1). Wolfe, D.T. and Hermanson, D.R. 2004. The Fraud Diamond Considering the Four Elements of Fraud. The CPA Journal, December, 1-5.

Yulianti, Pratami, Suci R, Yuni S Widowati, Lulus Prapti. 2019. "Influence Of Fraud Pentagon Toward Fraudulent Financial Reporting In Indonesia An Empirical Study On Financial Sector Listed In Indonesian Stock Exchange”. International Journal of Scientific \& Technology Research, Vol. 8 (8).

Yurmaini, 2017. "Kecurangan Akuntansi (Fraud Accounting) dalam Perspektif Islam”. Jurnal Akuntansi dan Bisnis.Vol. 3, (1). 